\title{
Oestrogen synthesis by the peri-implantation conceptus of the one-humped camel (Camelus dromedarius)
}

\author{
J. A. Skidmore ${ }^{1,2}$, W. R. Allen ${ }^{2 *}$ and R. B. Heap ${ }^{3}$ \\ ${ }^{1}$ The Camel Reproduction Laboratory, Nakhlee, Dubai, United Arab Emirates; ${ }^{2} T B A$ Equine Fertility \\ Unit, Mertoun Paddocks, Woodditton Road, Newmarket, Suffolk CB8 9BH, UK; and ${ }^{3}$ The Babraham \\ Institute, Babraham, Cambridge CB2 4AT, UK
}

\begin{abstract}
The ability of the embryonic tissues of the dromedary camel (Camelus dromedarius) to synthesize oestrogens in vitro was studied in 15 conceptuses recovered by non-surgical uterine lavage between 10 and 33 days after ovulation. Definitive evidence for strong aromatase activity with synthesis of considerable quantities of oestrogens was obtained at all stages when conceptus tissues were incubated with $\left[{ }^{3} \mathrm{H}\right]$ androstenedione. A high proportion of the oestrogens was in the form of oestradiol, which contrasts to the higher ratio of oestrone:oestradiol in the oestrogens synthesized by embryonic tissues of horses and pigs. Biopsies of endometrial tissue recovered from pregnant and nonpregnant camels showed great ability to conjugate both oestradiol and oestrone when incubated with tritium-labelled forms of these two hormones.
\end{abstract}

\section{Introduction}

In ungulates the embryo produces a chemical signal to the mother that prevents cyclical regression of the corpus luteum and maintains the pregnancy (Short, 1969; Heap et al., 1983). In cows and sheep, both of which are ruminants with a synepitheliochorial cotyledonary placenta (Wooding, 1992), the important maternal recognition of pregnancy factor secreted by the conceptus has been shown to be an $18 \mathrm{kDa}$ protein, which possesses strong anti-viral activity and shows close structural similarity to $\alpha$-interferon (Imakawa et al., 1987; Stewart et al., 1989).

Studies to date in pigs and horses, both of which have a diffuse, non-invasive epitheliochorial placenta (Amoroso, 1952), have indicated that interferon-like molecules of embryonic origin are probably not involved in maternal recognition of pregnancy (La Bonnardiere et al., 1991; Baker et al., 1991). However, the embryonic tissues of both these species possess high aromatase activity and they can synthesize large amounts of oestrogens in vitro from as early as day 10 after ovulation (Perry et al., 1973; Flood et al., 1979; Heap et al., 1982). The dromedary or one-humped camel is a ruminant but it has a diffuse, epitheliochorial placenta like that of pigs and horses (van Lennep, 1961). It is an induced ovulator (Chen et al., 1985; Anouassi $e t$ al., 1992) and the corpus luteum that develops after a sterile mating has a lifespan of only 8-10 days (Marie and Anouassi, 1987; J. A. Skidmore, unpublished data).

As part of a study of the mechanisms that may be involved in achieving maternal recognition of pregnancy and luteal maintenance in camelids, the present experiments were undertaken to assess the ability of camel embryonic tissues to

*Correspondence.

Received 23 October 1993. synthesize oestrogens from a common steroid precursor and of the endometrium to conjugate these products, as in pigs and horses.

\section{Materials and Methods}

\section{Animals}

Twenty-three female dromedary camels, aged 5-14 years, were each mated on two successive days to one of three fertile bull camels when repeated daily transrectal ultrasound examinations of their ovaries (Tinson and McKinnon, 1992) revealed the presence of one or more preovulatory follicles of 1.0 $2.0 \mathrm{~cm}$ diameter. Ovulation occurred $24-48 \mathrm{~h}$ after the first mating in 20 of these camels. It was diagnosed initially by ultrasound examination and confirmed subsequently by a rise in progesterone concentrations in samples of peripheral serum collected daily from the day of the first mating. An enzymelinked enhanced luminescent assay (Amerlite Diagnostics Ltd, Amersham, Bucks; Whitehead et al., 1983) validated for use with unextracted camel serum was used. This assay used a rabbit anti-progesterone serum that exhibited crossreactivities of $5.2 \%$ and $4.17 \%$, respectively, with $5 \alpha$ - and $5 \beta$-pregnane3,20 -dione, $1.1 \%$ with $20 \alpha$-dihydroprogesterone and $<0.5 \%$ with other progestagens. Standards were made up in male camel serum. The limit of sensitivity was $0.15 \mathrm{ng}$ progesterone $\mathrm{ml}^{-1}$ serum and the intra- and interassay coefficients of variation were, $7.2 \%$ and $8.4 \%$, respectively.

\section{Tissue recovery}

The uteri of the 20 camels that ovulated were flushed with embryo flushing medium (PBS pH 7.4; IMV, L'Aigle) at selected stages between 10 and 33 days after ovulation (day 0 ). 
A French 18-gauge two-way equine embryo recovery catheter with an inflatable cuff (Franklin Medical, Slough) was passed through the cervix via a gloved hand in the vagina and the uterine lumen was lavaged 4-6 times with $60-120 \mathrm{ml}$ PBS. Intact conceptuses were recovered on days 10 and 14 after ovulation and fragmented conceptus membranes were recovered at later stages from 15 of the camels flushed. It was not possible to identify the embryo in these tissue fragments and no special attempt was made to include or exclude embryonic tissue per se in the incubations. Nevertheless, the material incubated is referred to as embryonic tissues.

The ability of endometrium to conjugate oestrogens was assessed by taking endometrial biopsies from three pregnant and three non-pregnant camels on days 10 and 18 after ovulation, after having first flushed the uterus as described above.

\section{Tissue incubations}

The tissues recovered from each uterine flushing were lightly blotted on hardened filter paper (No. 540; Whatman's International, Maidstone), weighed and chopped finely using a scalpel blade and forceps. Known masses of all the minced tissues were then incubated at $37^{\circ} \mathrm{C}$ for $3 \mathrm{~h}$ in $5 \mathrm{ml}$ of Medium 199 (Flow Laboratories, Irvine) containing $\left[{ }^{3} \mathrm{H}\right]$ androstenedione (specific activity $3.55 \mathrm{TBq} \mathrm{mmol}^{-1}$; Amersham International, Aylesbury) at a constant ratio of $1 \mu \mathrm{Ci}$ per $60 \mathrm{mg}$ wet weight of tissue.

The endometrial biopsies were also minced finely, and known masses of these homogenates were incubated similarly, in duplicate, with known concentrations of (a) $\left[{ }^{3} \mathrm{H}\right]$ oestradiol ( $1 \mu \mathrm{Ci}$ per $60 \mathrm{mg}$ tissue; specific activity $1.5 \mathrm{TBq} \mathrm{mmol}^{-1}$ ); (b) $\left[{ }^{3} \mathrm{H}\right]$ oestrone $(1 \mu \mathrm{Ci}$ per $60 \mathrm{mg}$ tissue; specific activity $3.0 \mathrm{TBq} \mathrm{mmol}{ }^{-1}$ ); (c) $\left[{ }^{3} \mathrm{H}\right]$ oestrone sulfate $(1 \mu \mathrm{Ci}$ per $60 \mathrm{mg}$ tissue; specific activity $1.77 \mathrm{TBq} \mathrm{mmol}^{-1}$ ) or (d) $\left[{ }^{3} \mathrm{H}\right]$ androstenedione ( $1 \mu \mathrm{Ci}$ per $60 \mathrm{mg}$ tissue; specific activity $3.55 \mathrm{TBq}$ $\mathrm{mmol}^{-1}$; Amersham International).

The incubation flask was rotated gently at intervals of $30 \mathrm{~min}$ during the $3 \mathrm{~h}$ incubation, which was carried out at $37^{\circ} \mathrm{C}$ in an atmosphere of $5 \% \mathrm{CO}_{2}$ in $\mathrm{O}_{2}$. At the end of the incubation, the contents of the flask were decanted into a $30 \mathrm{ml}$ glass universal tube containing $0.25 \mathrm{kBq}\left[{ }^{14} \mathrm{C}\right]$ oestrone (specific activity $578 \mathrm{kBq} \mu \mathrm{mol}^{-1}$ ) and $0.25 \mathrm{kBq}\left[{ }^{14} \mathrm{C}\right.$ loestradiol (specific

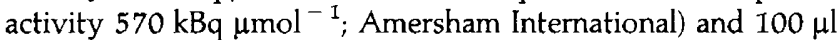
of unlabelled oestrone and $100 \mu \mathrm{l}$ of oestradiol ( $1 \mathrm{mg} \mathrm{ml}^{-1}$ in ethanol; Sigma Chemical Co., Poole, Dorset), added to correct for procedural losses. In all cases medium blanks were incubated separately.

\section{Extraction and identification of steroid products}

Unconjugated steroids in the culture medium were extracted by shaking all $6 \mathrm{ml}$ of incubation medium vigorously with $2 \times 10 \mathrm{ml}$ of diethyl ether for 1 min each time as described by Gadsby et al. (1980). The solvent phase was then decanted and taken to dryness under a stream of nitrogen. The resulting steroids were further separated into neutral and phenolic phases by shaking vigorously with $10 \mathrm{ml}$ chloroform:carbon tetrachloride (1:5, v:v British Drug Houses, Upminster, Essex) and $10 \mathrm{ml}$ of $1 \mathrm{~mol} \mathrm{NaOH} 1^{-1}$ for $1 \mathrm{~min}$. The phenolic steroids were extracted from the $\mathrm{NaOH}$ layer by shaking with $20 \mathrm{ml}$ diethyl ether before both phenolic and neutral phases were taken to dryness under a stream of nitrogen. The extracted steroids were redissolved in $1 \mathrm{ml}$ ethanol, allowed to equilibrate overnight and taken to dryness under nitrogen before application in $100 \mu \mathrm{l}$ methylene chloride to a silica-coated thin-layer chromatography (TLC) plate (Kiesel Gel 60F 254 ; Merck, Darmsted), together with oestrone and oestradiol standards in marker lanes. Unconjugated steroids in the phenolic phase were separated using the technique described by Challis et al. (1973), except that the plate was developed in a solvent system consisting of methylene chloride and diethyl ether mixed in a ratio of $7: 3(\mathrm{v}: \mathrm{v})$. The radioactivity was located using a radiochromatogram scanner and the steroids were recovered from the silica gel by scraping the appropriate zones into separate $1 \mathrm{ml}$ disposable pipette tips (Gilson Medical Electronics, Villiers-le-Bel) plugged with pre-washed quartz wool. Elution into glass vials was achieved by washing the silica gel with $3 \times 1 \mathrm{ml}$ aliquots of ethanol. After evaporation under a stream of nitrogen, a further $1 \mathrm{ml}$ of ethanol was added to each vial and radioactivity was measured in $100 \mu \mathrm{l}$ aliquots. Values were corrected for procedural losses and expressed as the percentages of labelled precursor incorporated into chromatographically separable oestrone and oestradiol.

In the endometrial incubations designed to assess the ability of the endometrium to conjugate oestrogens produced by the conceptus, the aqueous phases from the tritiated oestrone and oestradiol incubations were solvolysed. Any residual ether associated with the original aqueous phase was removed under a stream of nitrogen and the sample subsequently made up to $10 \mathrm{ml}$ with distilled water. The radioactivity in $500 \mu \mathrm{l}$ was to provide a measure of the total amount of determined conjugated steroids present. For solvolysis, $2 \mathrm{ml}$ aliquots from each aqueous phase in the same group were pooled and $1.2 \mathrm{~g} \mathrm{NaCl}$ (Sigma Chemical Co.) added to a $5 \mathrm{ml}$ aliquot of this aqueous pool. This was followed by the addition of $0.18 \mathrm{ml} 5 \mathrm{~mol}$ $\mathrm{H}_{2} \mathrm{SO}_{4} \mathrm{l}^{-1}$ and $15 \mathrm{ml}$ ethyl acetate (Sigma Chemical Co.) and the vials were rotated overnight at $4^{\circ} \mathrm{C}$. All vials were subsequently shaken for $1 \mathrm{~min}$ and centrifuged at $500 \mathrm{~g}$ for $20 \mathrm{~min}$ before the ethyl acetate layer was transferred to tubes containing $0.25 \mathrm{kBq}\left[{ }^{14} \mathrm{C}\right]$ oestrone and $0.25 \mathrm{kBq}$ $\left[{ }^{14}\right.$ Cloestradiol and $100 \mu \mathrm{l}$ each of unlabelled oestrone and oestradiol, added to protect any solvolysed steroids and to monitor the procedural losses. The tubes were then incubated at $45^{\circ} \mathrm{C}$ for $3 \mathrm{~h}$ in a shaking water bath before they were cooled, washed once with bicarbonate buffer $(\mathrm{pH})$ and twice with distilled $\mathrm{H}_{2} \mathrm{O}$ and dried down under nitrogen. The resulting steroids were taken up in $10 \mathrm{ml}$ chloroform:carbon tetrachloride $(1: 5, \mathrm{v}: \mathrm{v})$ containing $10 \mathrm{ml} 1 \mathrm{~mol} \mathrm{NaOH} \mathrm{l}{ }^{-1}$, separated into neutral and phenolic fractions and rechromatographed as described previously. Finally, the authenticity of the isolated steroids was demonstrated by recrystallization to constant specific radioactivity, using the method of Axelrod et al. (1965).

\section{Results}

Aromatase activity was very high in the tissues of the young camel conceptus. In all 15 incubations of tissues recovered between 10 and 33 days after ovulation, over $60 \%$ of the 
Table 1. Aromatase activity of the embryonic tissues of dromedary camel conceptuses following incubation with $\left[{ }^{3} \mathrm{H}\right]$ androstenedione

\begin{tabular}{|c|c|c|c|c|c|c|c|}
\hline \multirow{2}{*}{$\begin{array}{l}\text { Stage of } \\
\text { pregnancy } \\
\text { (days) }\end{array}$} & \multirow[b]{2}{*}{$\begin{array}{l}\text { Number of } \\
\text { animals }\end{array}$} & \multirow[b]{2}{*}{$\begin{array}{l}\text { Mass of wet } \\
\text { tissues (mg) }\end{array}$} & \multicolumn{4}{|c|}{ Percentage of ether extractable activity recovered as: } & \multirow[b]{2}{*}{$\begin{array}{c}\text { Oestradiol:oestrone } \\
\text { ratio }\end{array}$} \\
\hline & & & Oestrone & Oestradiol & $\begin{array}{c}\text { Androstenedione } \\
\text { substrate }\end{array}$ & Aqueous soluble & \\
\hline 10 & 3 & $51.7 \pm 18.8$ & $11.0 \pm 4.0$ & $42.4 \pm 21.1$ & $22.0 \pm 2.3$ & $21.0 \pm 8.7$ & $4.5 \pm 1.4$ \\
\hline 14 & 3 & $102.3 \pm 15.9$ & $11.1 \pm 0.6$ & $61.3 \pm 17.3$ & $3.0 \pm 3.1$ & $18.6 \pm 1.3$ & $5.6 \pm 1.6$ \\
\hline 18 & 3 & $103.0 \pm 33.3$ & $17.3 \pm 1.3$ & $58.5 \pm 0.4$ & $5.2 \pm 2.7$ & $15.8 \pm 3.1$ & $3.6 \pm 0.1$ \\
\hline 22 & 3 & $172.0 \pm 43.3$ & $23.0 \pm 6.6$ & $64.3 \pm 3.9$ & 0 & $14.0 \pm 0.6$ & $3.2 \pm 0.6$ \\
\hline 33 & 3 & $119.0 \pm 30.5$ & $15.6 \pm 9.1$ & $18.7 \pm 9.7$ & $5.7 \pm 19.6$ & $10.7 \pm 2.6$ & $1.5 \pm 0.6$ \\
\hline Mean & & $109.6 \pm 19.5$ & $15.6 \pm 2.3$ & $49.0 \pm 8.6$ & $7.2 \pm 3.9$ & $16.0 \pm 1.8$ & $3.7 \pm 0.7$ \\
\hline
\end{tabular}

Values are means $\pm \mathrm{SEM}$.

Table 2. Percentage of substrate recovered in oestrone, oestradiol and aqueous fractions after incubation with non-pregnant (NP) and pregnant $(\mathrm{P})$ endometrium of dromedary camels

\begin{tabular}{|c|c|c|c|c|c|c|c|}
\hline \multirow[b]{2}{*}{ Substrate } & \multirow{2}{*}{$\begin{array}{c}\text { Stage } \\
\text { (day after } \\
\text { ovulation) }\end{array}$} & \multicolumn{2}{|c|}{ Oestrone } & \multicolumn{2}{|c|}{ Oestradiol } & \multicolumn{2}{|c|}{ Aqueous } \\
\hline & & $\mathrm{NP}$ & $\mathrm{P}$ & NP & $\mathrm{P}$ & $\mathrm{NP}$ & $P$ \\
\hline \multirow[t]{4}{*}[{}^{3}\mathrm{H}]{ Androstenedione } & 10 & $0.3 \pm 0.1$ & $0.2 \pm 0.1$ & $0.2 \pm 0.1$ & $0.2 \pm 0.1$ & $6.6 \pm 1.2$ & $4.7 \pm 0.3$ \\
\hline & $\mathrm{C}$ & $0.2 \pm 0.1$ & $0.1 \pm 0.1$ & $0.2 \pm 0.1$ & $0.1 \pm 0.0$ & $4.0 \pm 1.3$ & $3.1 \pm 0.4$ \\
\hline & 18 & $0.1 \pm 0.1$ & $0.2 \pm 0.1$ & $0.2 \pm 0.2$ & $0.2 \pm 0.1$ & $4.5 \pm 0.2$ & $6.1 \pm 0.5$ \\
\hline & C & $0.1 \pm 0.0$ & $0.1 \pm 0.0$ & $0.2 \pm 0.1$ & $0.1 \pm 0.1$ & $2.6 \pm 0.1$ & $3.3 \pm 0.3$ \\
\hline \multirow[t]{4}{*}[{}^{3}\mathrm{H}]{ Oestrone sulfate } & 10 & $13.9 \pm 0.9^{\mathrm{a}}$ & $8.5 \pm 1.3^{b}$ & $0.5 \pm 0.2$ & $1.0 \pm 3.9$ & $71.1 \pm 0.4$ & $70.8 \pm 4.1$ \\
\hline & C & $3.2 \pm 0.9^{\mathrm{a}}$ & $2.9 \pm 1.2^{b}$ & $0.2 \pm 0.1$ & $0.2 \pm 0.1$ & $84.1 \pm 3.8$ & $66.8 \pm 7.3$ \\
\hline & 18 & $12.5 \pm 7.3^{c}$ & $13.3 \pm 1.7^{\mathrm{d}}$ & $0.2 \pm 0.1$ & $0.5 \pm 0.1$ & $65.7 \pm 3.9$ & $67.9 \pm 3.5$ \\
\hline & C & $2.8 \pm 0.6^{c}$ & $2.1 \pm 0.9^{\mathrm{d}}$ & $0.2 \pm 0.1$ & $0.4 \pm 3.3$ & $80.6 \pm 2.9$ & $62.0 \pm 17.8$ \\
\hline
\end{tabular}

Values are means \pm SEM. ( $n=3$ animals in each group).

C: control sample, no tissue added.

Means with the same superscript are significantly different (Student's $t$ test) ${ }^{a} P<0.01 ;{ }^{b} P<0.05 ;{ }^{c} P<0.01 ;{ }^{d} P<0.05$.

substrate, $\left[{ }^{3} \mathrm{H}\right]$ androstenedione, was converted to oestrone $(15.6 \pm 2.3 \%)$ and oestradiol $(49.0 \pm 8.6 \%$; Table 1$)$. The radiochromatogram scans all showed a single peak of unmetabolized androstenedione in the control medium containing no tissue, whereas in the equivalent medium incubated with conceptus membranes the androstenedione was metabolized almost completely to oestrone and oestradiol. Only in one day 10 sample, in which the amount of tissue that was incubated was very small $(3 \mathrm{mg})$, did any appreciable quantity of substrate remain after the $3 \mathrm{~h}$ incubation. The amount of oestradiol recovered from androstenedione was much greater than that of oestrone, thereby indicating the presence of an active $17 \beta$-oxidoreductase. However, a relatively small amount of radioactivity was recovered in the aqueous phase, indicating low sulfotransferase activity in embryonic tissues at these stages.

In contrast, the results of the endometrial incubations showed that the endometrium did not metabolize $\left[{ }^{3} \mathrm{H}\right]$ androstenedione into either oestrone or oestradiol. Oestrone sulfate was hydrolysed to oestrone to a small extent in both the day 10 and day 18 pregnant and non-pregnant animals
(Table 2), but the formation of oestradiol was not significantly different from that of the control incubations. However, incubation of the endometrium with $\left[{ }^{3} \mathrm{H}\right]$ oestrone or $\left[{ }^{3} \mathrm{H}\right]$ oestradiol resulted in a substantial amount of radioactivity in the aqueous phase compared with the control samples without tissue (Table 3), indicating that the oestrone or oestradiol had been conjugated. Solvolysis confirmed the high rate of conjugation that had been achieved in the original incubations (Table 3). In all experiments there was no difference between pregnant and non-pregnant animals.

\section{Discussion}

These results demonstrated clearly that, like the tissues of pig and horse conceptuses (Gadsby et al., 1980; Heap et al., 1982), the tissues of young camel conceptuses possess considerable aromatizing activity. Strikingly large amounts of oestrone and oestradiol were synthesized during short-term incubations of embryonic tissues with the C-19 precursor of oestrogens, androstenedione. However, in contrast to pig and horse tissues, 
Table 3. Percentage recovery of substrate in the aqueous fraction and subsequent solvolysis of radiolabelled compounds recovered from this aqueous fraction following incubation of endometrial tissue from non-pregnant (NP) and pregnant (P) dromedary camels

\begin{tabular}{|c|c|c|c|c|c|c|c|}
\hline \multirow[b]{2}{*}{ Substrate } & \multirow{2}{*}{$\begin{array}{c}\text { Stage } \\
\text { (day after } \\
\text { ovulation) }\end{array}$} & \multicolumn{2}{|c|}{ Aqueous } & \multicolumn{2}{|c|}{ Percentage converted to oestrone } & \multicolumn{2}{|c|}{ Percentage converted to oestradio } \\
\hline & & NP & $P$ & NP & $\mathrm{P}$ & NP & $\mathrm{P}$ \\
\hline \multirow[t]{4}{*}[{}^{3}\mathrm{H}]{ Oestrone } & 10 & $44.8 \pm 10.7$ & $24.7 \pm 5.1$ & $46.5,60.0$ & $30.0,21.8$ & $1.3,1.1$ & $0.6,0.6$ \\
\hline & $\mathrm{C}$ & $4.8 \pm 0.9$ & $2.2 \pm 0.9$ & - & - & - & - \\
\hline & 18 & $32.5 \pm 3.7$ & $23.4 \pm 4.1$ & $30.1,30.0$ & $19.2,20.1$ & $0.6,0.9$ & $0.7,0.7$ \\
\hline & $\mathrm{C}$ & $1.8 \pm 0.3$ & $3.3 \pm 0.7$ & - & - & - & - \\
\hline \multirow[t]{4}{*}[{}^{3}\mathrm{H}]{ Oestradiol } & 10 & $31.9 \pm 3.4$ & $20.5 \pm 3.7$ & $0.6,0.6$ & $0.4,0.4$ & $39.9,42.4$ & $27.5,29.5$ \\
\hline & $\mathrm{C}$ & $5.2 \pm 0.1$ & $2.3 \pm 0.9$ & - & - & - & - \\
\hline & 18 & $13.9 \pm 2.0$ & $24.6 \pm 0.9$ & $0.5,0.3$ & $0.4,0.2$ & $12.5,9.4$ & $24.0,22.0$ \\
\hline & $\mathrm{C}$ & $4.1 \pm 0.2$ & $3.4 \pm 1.0$ & - & - & - & - \\
\hline
\end{tabular}

Values are means \pm SEM. ( $n=3$ animals per group).

Aqueous fractions from each group were pooled before solvolysis and subsequent separation of oestrogens by ether extraction and TLC.

the camel tissues synthesize considerably more oestradiol than oestrone from a C-19 precursor. Incubation of pregnant and non-pregnant endometrium with oestrone and oestradiol demonstrated a ready ability of this tissue to conjugate these oestrogens and so diminish their biological potencies.

This high level of steroid metabolic capability was present by 10 days after ovulation in embryos that were just beginning to elongate. Thus, the rapid onset of oestrogen secretion by embryonic tissues coincides with the observed time of luteolysis following a sterile mating, prompting the suggestion that oestrogens of embryonic origin could be produced in camelids when a signal is required from the embryo to maintain luteal function. However, it also begs the question of how such a tiny, spherical embryo could bring sufficient of its antiluteolytic signal onto the surface of a large enough area of endometrium to prevent the release of luteolytic quantities of $\mathrm{PGF}_{2 \alpha}$ required for luteolysis in this species.

In pregnant gilts, Bazer and Thatcher (1977) proposed that the oestrogens produced by the rapidly elongating blastocysts between day 10 and day 16 after ovulation function to redirect endometrial $\mathrm{PGF}_{2 \alpha}$ secreted by the glandular epithelium away from the venous effluent and into the uterine lumen, thereby protecting the corpus luteum from its potentially luteolytic action. Camels, although ruminants like cows and sheep (Arthur et al., 1985), have a non-invasive epitheliochorial placenta like those of pigs and horses (Amoroso, 1952; van Lennep, 1961) and, as shown in the study reported here, camel placental tissues, like those of pigs and horses, also exhibit very high aromatase activity. Preliminary studies have failed to detect any sign of anti-viral activity in $24 \mathrm{~h}$ incubates of young camel conceptuses (J. A. Skidmore, F. Stewart and B. Charleston, unpublished data) and it is therefore possible that, in the dromedary camel, as in pigs (Bazer and Thatcher, 1977) and perhaps also in horses (Allen, 1992), oestrogens of embryonic origin are produced at a critical stage corresponding to the maternal recognition of pregnancy. They may play a key role in maintaining luteal function during pregnancy that facilitates non-invasive epitheliochorial placentation for fetal sustenance throughout gestation.
The authors are grateful to $\mathrm{M}$. Billah for assistance with recovery of the camel conceptus tissues and M. Hamon for expert advice with the extraction and identification of steroid hormones. The study was kindly sponsored by H. H. Sheikh Mohammed bin Rashid al Maktoum of Dubai.

\section{References}

Allen WR (1992) The diagnosis and handling of early gestational abnormalities in the mare Animal Reproduction Science 28 31-38

Amoroso EC (1952) Placentation. In Marshall's Physiology of Reproduction (3rd Edn) Vol 2 pp 127-297 Ed. AS Parkes. Longmans Green, London

Anouassi A, Adnani M and El Raed (1992) Artificial insemination in the camel requires induction of ovulation to achieve pregnancy Proceedings of the First International Camel Conference pp 175-178 Eds WR Allen, AJ Higgins, IG Mayhew, DH Snow and JF Wade. R \& W Publications, Newmarket

Arthur GH, Al Rahim AT and Al-Hindi AS (1985) The camel in health and disease. 7. Reproduction and genital diseases of the camel British Veterinary Journal $141650-659$

Axelrod LR, Matthijssen C, Goldzieber JW and Pulliam JE (1965) Definitive identification of microquantities of radioactive steroids by recrystallization to constant specific activity. Acta Endocrinologica 99 71-77 (Supplement)

Baker CB, Adams MH and McDowell KJ (1991) Lack of expression of alpha or omega interferons by the horse conceptus Joumal of Reproduction and Fertility Supplement 44 439-443

Bazer FW and Thatcher WW (1977) Theory of maternal recognition of pregnancy in swine based on estrogen controlled endocrine versus exocrine secretion of prostaglandin $\mathrm{F}_{2 \alpha}$ by the uterine endometrium Prostaglandins 14 $397-400$

Challis JG, Harrison F and Heap RB (1973) The metabolic clearance rate, production rate and conversion ratios of oestrone in the sheep Journal of Endocrinology 58 435-446

Chen BX, Yuen ZX and Pan GW (1985) Semen-induced ovulation in the bactrian camel (Camelus bactrianus) Joumal of Reproduction and Fertility $\mathbf{7 4}$ 335-339

Flood PF, Betteridge KJ and Irvine DS (1979) Oestrogens and androgens in blastocoelic fluid and cultures of cells from equine conceptuses of 10-22 days gestation Joumal of Reproduction and Fertility Supplement 27 412-420

Gadsby JE, Heap RB and Burton RD (1980) Oestrogen production by blastocyst and early embryonic tissue of various species Journal of Reproduction and Fertility 60 409-417

Heap RB, Hamon M and Allen WR (1982) Studies on oestrogen synthesis by the pre-implantation equine conceptus Joumal of Reproduction and Fertility Supplement 32 343-352

Downloaded from Bioscientifica.com at 04/26/2023 01:07:15PM 
Heap RB, Staples LD, Flint APF, Maule Walker FM and Allen WR (1983) Synthetic capabilities of the preimplantation conceptus and maternal response to pregnancy. In Fertilization of the Human Egg in vitro - Biological Basis and Clinical Applications, pp 387-411 Eds HM Beier and HR Lindner. Springer Verlag, Berlin

Imakawa K, Anthony RV, Kazemi M, Marotti KR, Polites HG and Roberts RM (1987) Interferon-like sequence of ovine trophoblast protein secreted by embryonic trophectoderm Nature 330 377-379

La Bonnardiere C, Martinat-Botte F, Terqui M, Le Feure F, Zonari K, Martal J and Bazer FW (1991) Production of two species of interferon by Large White and Meishan pig conceptuses during the peri-implantation period Journal of Reproduction and Ferility 91 469-478

Marie M and Anouassi A (1987) Induction of luteal activity and progesterone secretion in the non-pregnant one-humped camel (Camelus dromedarius) Journal of Reproduction and Fertility 80 183-192

Perry JS, Heap RB and Amoroso EC (1973) Steroid hormone production by pig blastocysts Nature $245 \quad 45-47$

Short RV (1969) Implantation and maternal recognition of pregnancy. In Ciba Foundation Symposium on Foetal Autonomy pp 2-26 Eds GEW Wolstenholme and M O'Connor. J and A Churchill, London
Stewart HJ, McCann SHE, Northrop AJ, Lamming GE and Flint APF (1989) Sheep anti-luteolytic interferon cDNA sequence and analysis of mRNA levels Journal of Molecular Endocrinology 2 65-70

Tinson AH and McKinnon AO (1992) Ultrasonography of the reproductive tract of the female dromedary camel Proceedings of The First International Camel Conference pp 129-136 Eds WR Allen, AJ Higgins, IG Mayhew, DH Snow and JF Wade. R \& W Publications, Newmarket

van Lennep EW (1961) The histology of the placenta of the one-humped camel (Camelus dromedarius) during the first haif of pregnancy Acta Morphologica Neerlando Scandinavica 4 180-193

Whitehead TP, Thorpe GHG, Carter TJN, Groucutt C and Kricka LJ (1983) Enhanced luminescence procedure for sensitive determination of peroxidaselabelled conjugates in immunoassay Nature 305 158-159

Wooding FBP (1992) The synepitheliochorial placenta of ruminants: binucleate cell fusions and hormone production Placenta 13 101-113 